\title{
Linguistic and Discursive Features of Mining News Discourse in the Philippines
}

\author{
Jennifier Tabernero Diamante ${ }^{a}$ \\ jennifier.diamante@wpu.edu.ph \\ Western Philippines University, Philippines \\ Glenda Doroja Cadiente \\ glenda.cadiente@lnu.edu.ph \\ Leyte Normal University, Philippines \\ Romualdo Atibagos Mabuan ${ }^{b}$ \\ rmabuan@feu.edu.ph \\ Far Eastern University, Philippines
}

\begin{abstract}
The Philippines is one of the mineral-rich countries in the world with an estimated US $\$ 840$ billion worth of untapped mineral wealth, catapulting the mining industry as a significant economic player providing substantial contribution to the national revenue and generating employment opportunities for the Filipino people. However, the detrimental impact of mining to the country has also been heavily criticized as it causes massive potential destruction to environment and wildlife ecology such as acid mine drainage and contaminant leaching, soil erosion, and tailing impoundments among others. These conflicting interests are reflected in the mining discourses stoked or dimmed by media, which influence the readers' construal of meanings in the mining texts, social actors' roles in the mining industry, and the urderlying contexts of the mining reality. Drawing on critical discourse analysis, this study described the linguistic and discursive features of Philippine mining discourse in media texts. The study used 224 news articles published by three online portals within five years. Local news reports and peripheral discourses obtained through interviews with local "symbolic elites" in the identified mining communities and other archival documents supplemented the news texts. The UAM Corpus Tool, a software for linguistic tagging, complemented the manual analysis in identifying the social actor theme. Findings revealed that government actions, economic phenomenon, and political actors are the most prevalent themes in the mining news reports. Moreover, results showed that local news tends to focus more on the mining's environmental impact, whereas the national news tends to put more premium on the mining's economic impact. This means that the media allotted a much lesser spatio-temporal space for the environment and Indigenous Peoples' cause. The findings further invalidate the assumptions that mining discourse is primarily concerned with environmental related issues.
\end{abstract}

Keywords: sociolinguistics; discourse studies; critical discourse analysis; discourse themes; Philippine mining discourse

\section{INTRODUCTION}

According to Mayr (2008) news holds the consensual view that "...the journalist has an important role to play...in creating informed citizens aware of what is going on in society..." (p. 62). As such, journalism is bound by its duty to report on truthful, accurate, and reliable

${ }^{a}$ Main author

${ }^{b}$ Ccorresponding author 
events. As receivers of news, readers have the right not just to verify claims of truth but also to gain full awareness of what the news represents.

Critical Discourse Analysis (CDA) has been credited for revealing news representations (Garlitos, 2020; Mayr, 2005; Mohd Nor et al., 2021). In particular, news discourse has recently focused its lens on environmental issues in terms of how media representations have been constructed and transformed over time (Castrechini et al., 2014; Leipold et al., 2019). Their 15-year study which spanned from 1992 to 2006 in two Spanish newspapers revealed that media representation of the environment shifted from being associated with nature to predominantly associated with the urban environment. They observed that although there was an increase in environmental news reportage in the 2000s, most of those articles stressed urban and industrial landscapes (e.g. urban planning and development). They also claimed that there was a shift from scientific to political discourse in news texts. Finally, they recommended further exploration of news productions, themes in newspapers such as business interests as well as local actors and 'polluting' companies.

In another study, Deacon, Baxter, and Buzzelli (2015) explored the construction of environmental news discourse in 15 Canadian mainstream newspapers published from 2000 to 2012. Among other observations, they claimed that the Canadian press overtly ignored and subtly downplayed environmental threats (i.e., pollution) faced by marginalized local communities. This means that the disadvantaged communities who are directly experiencing environmental problems are consistently under-represented in the mainstream media coverage. Informed by these studies, we decided to embark on studying the media's construal of mining discourse in the country. Mining discourse, in this study, is defined as the ensemble of ideas, concepts, and categories describing the mining enterprise in the country.

This study aims to explore how environmental discourse, specifically on mining, is analyzed using the lens of Critical Discourse Analysis (CDA) in order to see what representations the news reports reveal in their writing. Being informed of environmental concerns is the responsibility of every Filipino citizen as it is the first step in safeguarding the country's natural wealth. In fact, the State promulgated Republic Act 9512 known as National Environmental Awareness and Education of 2008 to promote environmental awareness through environmental education and other purposes, to this effect.

The analyses of mining-related journals have already been the subject of studies abroad. Mining policy and mining politics proposed by the Government of Sweden in 2013 were the focus of Haikola and Anshelm's (2016) study. They analyzed the policies, editorial, and opinion pieces covering 2012 to 2014 from major and regional newspapers, and mining-related journals in the country. One significant highlight was the government's concealment of potential conflicts in the proposed developments. For example, the geographical visualizations of the minerals industry primarily consist of maps, charts, and photographs of minerals and mines but none of the images show local communities affected by mining establishments.

Özen and Özen (2016) also conducted an inquiry addressing the struggle between the local mining community and multinational companies (MNCs). They utilized a vast range of data collected from documentary sources such as websites of both protesting groups and the MNCs company reports and bulletins as well as relevant media reports, which appeared from 1999 to 2011 in the national and local daily newspapers with different political orientations, and online bulletins. They enriched their data with a series of in-depth interviews with protestors and company officials as the representatives of conflicting parties. In the end, the researchers posited that the existing conditions play a role in the emergence of struggles in (re)shaping the anti-mining and pro-mining discourses. They explained that the already prevalent discourses before the arrival of MNCs in the community triggered the emergence of conflicts between parties involved. 
In the Philippines, most, if not all, studies conducted on mining issues were directed at the environmental impact or the legal foundations governing the industry. For instance, Clemente (2019) presented several challenges in the Philippine mining industry including lack of proper environmental plans among mining companies, calling for the reviews of the legal framework to come up with policy recommendations to address such issues. In recent past, Chaloping-March (2011) focused on the socio-political and historical landscape defining the current mining policies in the country. Other studies were directed on the assessment of environmental damage caused by mining economic activities in Marinduque (e.g., Benagen, 1998; Gigantone et al., 2020; Plumlee et al., 2000), the power, politics, and protests in southern Philippines as regards social movement on coal mining dissent (Delina, 2020), the social issues behind activities of transnational mining corporations in Rapu-Rapu Island in Albay (Abanes, 2005), and, the prevailing issues relating to environmental impact assessment (EIA) process in the Philippines (Ingelson, Holden \& Bravante, 2009). More recently, De Vera-Ruiz (2017) found that several mine areas in the country were lacking proper environmental plans, with denuded forests and silted rivers as evidence of such uncontrolled degradation. Other similar studies were conducted by international groups such as the Foundation for Environmental Security and Sustainability (FESS) and the Centre for Biocultural Diversity (CBCD) of the University of Kent (UK) in partnership with the local NGO in Palawan, Ancestral Land/Domain Watch (ALDAW).

Hence, this study might be the first one to explore the issue from the linguistics vantage point. As FESS (2007) concludes, "As long as a large gap continues to exist between the rhetoric and reality of responsible mining, mineral extraction in the Philippines will remain a double-edged sword" (p.13).

\section{THE SOCIO-POLITICAL CONTEXT OF THE STUDY}

On July 6, 2012, President Benigno Aquino III issued Executive Order 79 (E.O. 79) to institutionalize reforms in the mining sector. The policy aimed at stricter implementation of environmental laws and the execution of "responsible mining practices" (p. 1) that are socially equitable and economically viable for the Filipino people. Two of the salient and contentious points of this policy rivet on increasing the $2 \%$ excise mining tax to $5 \%$ royalty tax for permits within mining reservation areas and 'shortening' of the mining contract from 50 to 25 years. The provision of Section 32 of the Philippine Mining Act (RA 7942) of 1995 stipulates that the mineral agreements shall not exceed 25 years but are renewable for another term under the same terms and conditions. However, Section 9 of E.O. 79's Implementing Rules and Regulations (IRR) as reflected in the DENR Administrative Order released on September 10, 2012, specifies that the second 25-year term of the contract will be negotiated with the government under new conditions. During the Mining Conference and Exhibition on September 19, 2012, the president of the Chamber of Mines of the Philippines (COMP), expressed that the new provision was 'illegal' and that the Chamber was planning to execute legal actions if the Philippine government pursued such legislation. However, on his third State of the Nation Address (SONA) on July 23, 2012 (almost three weeks after the issuance of E.O. 79), President Aquino seemed determined to pursue this legislation stating that "these natural resources are yours; it shouldn't happen that all that's left to you is a tip after they're extracted" (page number or par. \#). The President cited that of the 145 billion pesos derived from mining in 2010 only a fraction, 13.4 billion, or nine percent $(9 \%)$ was contributed to the national revenue (Aquino, III, 2012). On this occasion, the President also encouraged Congress to pass legislation that would address issues on environmental protection.

No sooner than its issuance, E.O. 79 had been the subject of media hype. Headlines like "The Mining EO: A mixed bag" (Rappler, July 12, 2012), "EO on mining not clear on 
sustainable development - Legarda", "Anti-mining advocate cheer new Aquino policy, but..." (Inq.Net, July 10, 2012), "Big mining Firms to sue government over 'illegal' rule" (Inq. Net, September 12, 2012), and "Group says mining policy full of lies" (Philstar.com, July 10, 2012), among others are proofs that the policy had gained reactions at varying degrees. While E.O.79 is 'illegal' in the eyes of capitalists, it is laudable for the environmentalists and other civic groups because they believe that it will 'institutionalize reforms' in the mining industry.

To further the enforcement of E.O. 79, President Aquino urged the concerned agencies and the mining corporations to commit to the process of Extractive Industries Transparency Initiative (EITI), a global standard of transparency. In December 2014, the first PH-EITI Report was published for fiscal year 2012, and the second covering the period of 2013 was published in the subsequent year. The 2015 Report shows that the tax contributions of mining from 2009 to 2014 to the national treasury averaged $1.2 \%$. The highest was in 2011 which was attributed mostly to high prices of metal in the global market, but the figure fell by $1.1 \%$ in 2012 because of low metal prices although it recovered in 2013-2014 as aided by the enforcement of legal mandates on excise tax and withholding tax on gold tax by small miners (PH-EITI, 2015). However, the PH-EITI Report also disclosed the discrepancies found between the figures reported by the government and the mining firms, prompting the organization to recommend for the continuing updates of the information database of the Mines and Geosciences Bureau (MGB).

Mining woes continued to the recently installed Duterte administration. It could be remembered that in his first SONA on July 26, 2016, President Rodrigo Duterte highlighted, among others, the intensification of military role in the drive against illegal logging and mining activities in the country (Duterte, 2016).

To this effect, his newly appointed DENR Secretary, Gina Lopez, who was known to be a staunch anti-mining advocate, launched a six-month audit on the operations of 41 largescale mining companies in the country. Lopez then recommended the closure of ten mining firms, suspension of 20, and approval of 11 companies' operations but ordered to correct some infractions, lest they, too, would be sanctioned (Gamil \& Domingo, 2016).

From an economic perspective, Goldman Sachs analysts projected that the mine closures in the Philippines would result in "nickel ore stocks falling to very low levels by March or April of 2017, driving a substantial rise in ore prices and thus marginal costs of nickel production over the next 3-6 months" (Reuters, September 27, 2016). Despite all these negative economic forecasts, the DENR Secretary, on February 2, 2017, ordered the permanent closure of the 23 mining firms in the country for allegedly destroying the watersheds and for the siltation of coastal waters and farmlands (Dumlao-Abadilla \& Nawal, 2017).

However, Lopez' appointment as the DENR Secretary ended in May 2017, when the Commission on Appointment (CA) denied her confirmation for the post. She bequeathed her seat to ex-Air Force of Philippines general, Roy A. Cimatu, a close ally of incumbent President Duterte. Shortly after Cimatu's assumption of the agency's top position, he lifted a restriction on issuing environmental permits to projects, including mine exploration and development, reversing a previous order by his predecessor (Reuters, July 6, 2017).

\section{RESEARCH QUESTIONS}

Given the dearth of literature exploring mining issues in the country from a linguistic lens, and from a CDA orientation, this study was conceptualized. It attempted to characterize mining discourse as constructed by the media and how linguistic features and discursive strategies found in the news formed representations of the mining discourse in the Philippines. Specifically, this paper sought answers to the following questions: 
1. How are mining issues discursively constructed in the media reports 2012 to 2017 in terms of:
1.1 Actors
1.2 Actions
1.3 Phenomena

2. How do these linguistic features and discursive strategies characterize the mining discourse in the Philippines?

\section{THEORETICAL BACKGROUND: CRITICAL DISCOURSE ANALYSIS (CDA)}

Critical Discourse Analysis (CDA), has been given a plethora of definitions by various scholars in the field. Two of its most-cited definitions include, "analysis of linguistic and semiotic aspects of social processes and problems" (Fairclough, Mulderrig, \& Wodak, 2011, p. 7); and, a method for tracing the links between language, power, and ideology (Machin \& Mayr, 2012). The second definition emphasizes the underpinnings of CDA inquiries - discourse, power, and ideology (Machin \& Mayr, 2012; Wodak \& Meyer; 2008; Fairclough, 1989). That is, CDA studies are always 'committed' to uncover the relationship between language and social realities, which is often problematic, thus needing critical investigation. The meaning-making pursuit is 'problematic' because discourse participants can obscure their communicative intentions through their linguistic strategies.

Media representations of societal issues have drawn significant attention from CDA analysts since the past decades. Fairclough (1989) claims that "In mass communication, text producers have effective means of manipulating audiences through attributing to their experience things which they want to get them to accept" (p. 153). This means that the media has the capacity to (re)frame certain realities and discourses in a way that conforms with their ideological positionings and institutional orientations.

In this context, CDA has been used in the (re)construction of the US-British and French-Arab newspapers of controversial issues regarding the alleged Iraqi possession of Weapons of Mass Destruction, Saddam's links to Al-Qaeda and the US officials' perspective about the legitimacy of attacking Iraq in 2003 (Sahlane, 2013). CDA has also been used to reveal strategies of Arab/Muslim alignment (Hakam, 2009) and provided a fitting approach to reveal the ideological representations within The New York Times and China Daily's news reports of an air collision involving the USA's surveillance plane and China's jet fighter (Li, 2001). The CDA lens revealed the ideological constructions of a territorial conflict between Nigeria and Cameroon as evidenced in their English-language newspapers (Taiwo and Igwebuike, 2015). CDA was also used to examine the discursive construction of ideologies and national identities during a diplomatic incident between China and Japan as reproduced by their respective media institutions (Chan, 2012).

Indeed, those who have access to power can always influence the structure of the media discourse and that media can always choose whether to sustain or contest political choices (Carvalho, 2005). Moreover, Sikka (2012) affirmed how CDA was able to uncover the special interests of some prominent entities, and how their discursive frames influenced the public, media and government discourses and actions led to the advocacy's fallout.

In more sophisticated studies, CDA researchers utilized a combined approach (e.g., Reisigl and Wodak's (2001/2009) Discourse Historical Approach (DHA), van Leeuwen's (2008) Social Actors Approach; van Dijk's (2001) Socio-Cognitive Approach; Fairclough's (2001) Dialectical-Relational Approach) to reveal the meanings buried in texts. 
This study employed a tripodal CDA framework with Reisigl and Wodak's (2009) DHA on the base and van Leeuwen's (2008) Social Actor Network, and van Dijk's (1988) semantic macro-structures of news reports as research arms.

Reisigl and Wodak's (2009) Discourse Historical Approach (DHA) noted that a fundamental element of DHA is its integration of the triangulation principle with fieldwork. Since DHA is interested in exploring how an event changed and evolved, it includes information about the background, political, and historical contexts on which a particular event under investigation is embedded. The framework follows a four-step-strategy analysis to account for the textual meaning and structure: (1) establishing of specific contents or topics of a specific discourse, (2) investigating the discursive strategies, and (3) examining the linguistic means and (4) the specific, context-dependent linguistic realization (Wodak, 2009).

Van Dijk's (1988) Thematic News Structure shows that a news report has identifiable thematic structure which may specify the context or situation. In this study, it is labeled as phenomena; the participants involved or the social actors; and the major events or actions and so on. A systematic analysis of the textual structure of news begins with an explication of notions of theme or topic and the main topics of news discourse may be routinely expressed by headlines and leads (opening paragraphs of news articles), and which act as summaries of news text (van Dijk, 1988).

An action theme occurs when the subject of the headline (HL) and/or the lead is a deactivated social action (van Leeuwen, 2008) such in the headline "Mining destroys farmers' lives - int'l group".

An actor theme is assigned if the subject of the HL and/or the lead of a news report is an individualized (e.g., senator, Lopez) or collectivized (e.g., Senate, the mining firm) social actor.

A phenomena theme is assigned if the subject of the HL and/or the lead is a societal event created/triggered by certain external forces which could be economic, environmental, social, and political. However, unlike in the two themes where the discourse topic is readily available in the HL or lead, it is not the case for the phenomena theme because sometimes the topic is implicitly stated. Thus, reading through the entire article is done to deduce the theme. For example, if only the HL, "Big nickel mining firm says rains caused pollution of the bay" will become the basis for identifying the theme, it would readily be classified under the actor category. However, the entire article talked about an environmental accident which allegedly caused the pollution of a body of water in a certain community. The quoted statement of a social actor in the second paragraph says, "The reported pollution is not due to siltation from our mining operations but because of rains, a natural phenomenon." News reports like this will be classified under the phenomena theme.

Van Leeuwen (2008) proposed a system that accounts for the representation of social actors in texts known as Social Actor Network. This framework interweaves a number of distinct lexico-grammatical and discourse-level linguistic schemes (e.g., membership categorization device, transitivity) that may unravel the system in representing social actors in texts. He explains that his preference for the term social actors over participants is motivated by the sociological concept attached to the former and the linguistic or grammatical sense to the other. Considering its sociological orientation, this study follows van Leeuwen's view in using the term social actors to refer to the participants and text producers of mining discourse. 


\section{METHOD}

\section{RESEARCH DESIGN}

The study is qualitative, employing a descriptive-analytic design. It describes the discursive strategies and linguistic features of mining discourse in the Philippines as reflected in the national news reports on mining issues. Following the triangulation principle of DHA, local news articles in the identified mining community, archival documents, and discourses of local "elites" were likewise analyzed to further characterize the mining discourse in the country.

\section{DATA DESCRIPTION}

A sample of 224 mining news reports published by Inquirer.Net, Manila Bulletin Online, and Philstar.com. from July 1, 2012, to June 30, 2017 were analyzed. The five-year period reflects significant temporal markers (e.g. issuance of E.O.79, appointments of DENR secretaries) that may have contributed to the discursive construction of mining discourse in the country, which makes this inquiry "historical" in nature. Reisigl and Wodak (2009) explained that a DHA investigation could take off from the analysis of "controversial positions" or contradictory positions of prominent social actors involved. Hence, the specified period was considered.

The three online news portals were chosen as data sources because their printed editions were the leading broadsheets in the country in terms of readership and circulation according to the Strategic Consumer Media Incites survey in 2014 and the 2015 First Quarter Consumer and Media View survey by the Nielsen Corporation (Inquirer.Net, May 11, 2015). The mining issue was selected as the topic because of the three pressing issues during the conceptualization of the study: (1) the planned permanent closure of 23 mining companies and suspension of five others, was estimated to lose 67,000 jobs and directly affect 1.2 million Filipinos (Cordero, 2017); (2) the issue gained national and international media coverage; and (3) the country's key officials had taken up dichotomized positions over the controversy which might had influenced the kind of news reportage and the discourses produced by the concerned entities.

A total of 27 news articles from the 112 weekly issues (1,165 news stories) of The Palawan Times that were found directly related to mining issues became part of the secondary data. Following Pennycook (2010) who stressed the importance of language practices of the grassroots or the peripheral discourses, the local news reports were supplemented by interviews with the "local elites" and the "ordinary individuals" in the mining communities to enrich the interpretation of the data.

\section{DATA ANALYSIS}

Two university professors with doctorate degrees in Applied Linguistics served as inter-coders. They analyzed the $30 \%$ or 67 news articles from the three online news portals. Consistent with van Dijk's (1988) framework on the news structure, the discursive theme categories were identified based on the headlines and leads of news reports. All coding discrepancies were resolved before finalizing the findings. The UAM Corpus Tool, a software used for linguistic tagging of participants or subject of the sentence or English clause based on Halliday's (2004) transitivity system was used to enrich the discussion of the actor theme category.

Due to space constraints, a detailed presentation of the social actor analysis (van Leeuwen, 2008) was provided in this paper but was only used as reference whenever necessary. For the same reason, a detailed presentation of local discourses might not be provided but was cited whenever needed. 


\section{RESULTS AND DISCUSSION}

This section presents the findings of the study. The prevailing discursive themes and the linguistic features of news reports that characterize the "Philippine mining discourse" will be presented and discussed.

\section{ON NATIONAL NEWS REPORTS}

Table 1 presents a summary of themes across five years. Subsequent discussion of the findings follows after the tabular presentation.

TABLE 1. Distribution of themes in national news reports from 2012 to 2017

\begin{tabular}{lcccc}
\hline Year & Action & Actor & Phenomena & Total \\
\hline 2012 & 9 & 9 & 11 & 29 \\
2013 & 4 & 10 & 9 & 23 \\
2014 & 16 & 5 & 13 & 34 \\
2015 & 6 & 5 & 13 & 24 \\
2016 & 23 & 17 & 19 & 59 \\
2017 & 25 & 17 & 12 & 54 \\
\hline Total & 83 & 62 & 79 & 224 \\
\hline
\end{tabular}

Table 1 shows the predominance of actions ( 83 or $37.05 \%$ ) followed by phenomena ( 79 or $35.38 \%$ ) and finally, by the actors theme category (62 or $27.68 \%$ ). The result indicates the tendency of the media to foreground the actions undertaken by 'prominent' social actors, while mining-related events come close second.

\section{ON ACTION THEME}

A sample of an action theme is seen in (1). The news article reports the finding of the international group, IFFEM, who conducted a study on the impact of mining activities on the lives of farmers and fisherfolk in the northern and southern parts of Negros Occidental. One of the findings that was highlighted was the decrease of the fisherfolks' livelihood by 700 percent in areas affected by magnetite mining in Sagay. It also reports the lamentations of the farmers in Hinoba-an and Sipalay of lower production and destruction of portions of their farmlands, while their children suffer skin diseases from polluted water.

(1) Mining destroys farmers' lives - int'l group

BACOLOD CITY, Philippines - Mining operations in Negros Occidental have destroyed the lives of poor farmers in the province, according to the International Fact-Finding and Environmental Mission (IFFEM) group that conducted a study of mining operations in this area last week. [Emphasis added]

(Dangcalan, 2012)

The most-prevailing action in 2012 was the issuance of E.O. 79 (as discussed in the Introduction section). This perhaps was the most controversial action undertaken by the government in 2012 that badly hit the mining sector. The news reports published on this topic delved mostly on the opposing views of the pro- and the anti-mining groups in the country and 
the projected detrimental impact on the economy, but a little underscored the environmental implication of the issuance.

Unlike in 2012 where the actions of the government received significant attention from the media, in 2013, news reports foregrounding the actions either of the government or the private sectors are much lesser. The majority of news stories were about community-based organizations or individualized exploit such as the campaign launched against the foreign firms by Church-based Federation of Environmental Advocates of Cagayan, a church-based organization, stopping the relentless hauling of black-sand along the coastlines of Cagayan Province as hinted by the headline in (2).

$$
\text { "Signature drive on vs black sand mining in Cagayan" }
$$

(Catindig \& Lagasca, 2013)

The action theme in 2014 originated chiefly from the mining industry disputing E.O. 79 issued in 2012. Perhaps, the effects of the policy are now felt by the sector, hence the finding. Although the headline in extract (3) does not directly reflect the action, the subject of its lead, and the rest of the article discussed about the adverse economic impact of the government's initiative towards the mining industry, i.e. decreased investments, lost opportunities to take advantage on the surge in mineral prices in the world market, and the new tax regime that severely affected their revenues.

(3) "Mining hobbled by gov't 'fixation' on taxes"

The Aquino administration's proposal to hike taxes on the Philippine mining industry to an effective rate of as high as 81 percent of a company's net income may result in the government drawing in less revenue from the sector-the exact opposite effect of what it hopes to achieve.

(Lucas, 2014)

The lower frequencies of the action theme in Table 1 for 2015 after 2013 indicate the absence of significant actions from the government that (in)directly concerned the mining industry. There were, however, community-based issues that resurfaced this year such as the black-sand mining in Cagayan that first emerged in 2013 as may be seen in (4).

(4) "Black sand mining in Cagayan goes offshore"

BAYOMBONG, Nueva Vizcaya-Large-scale mining operations for magnetite are shifting to offshore areas in the northern towns of Cagayan province, records of the Mines and Geosciences Bureau (MGB) showed.

(Gascon, 2015)

In the 2013 article, the identity of the concerned entities was masked, simply referring to them as "foreign firms". In (4), a more detailed description of the firms was provided including details of the contract they entered with the government. In response, the residents and the non-governmental organizations (NGOs) vowed to be more vigilant on the actions of the two parties.

Table 1 further shows that the peaks of the action theme are in 2016 and 2017. It was in 2016 when Gina Lopez, former DENR Secretary, launched an audit on the 41 large-scale metallic mining operations in the country which resulted in the suspension and closure of the majority of the firms. And consequently, the rejection of her confirmation in the DENR post in the subsequent year. These said actions are considered the two most "controversial" moves of the government within the five years as suggested by the volumes of published news reports. Most news articles in 2016 take on different angles of the actions performed by social actors from various sectors such as the impact of the government's initiatives, the positions of various 
personalities such in (5), and the plight of ordinary people especially the marginalized groups such as the indigenous peoples (IPs) as shown in (6).

(5) "Mining to stay but under tighter rules"

Mining is bound to carry on in the Philippines as many companies, especially those that are publicly listed, have no choice but to follow regulations and industry standards, according to Sen. Cynthia Villar.

(Domingo, 2016)

Extract (5) emphasizes the discourse position of the named political actor, who was then-chair of the Senate Committee on Environment and Natural Resources. She opines that mining companies should only comply with the environmental standards imposed by the government for them to continue their operations "the government should, of course, do a balancing act - encourage investors by putting in place the right business environment and, at the same time, be vigilant against abuses" (para. 7).

Another theme that was made apparent by the media is the plight of IPs as bared in (6). Issues such as killings and land grabbing are the subjects of the report.

(6) "Killings, land grabs threaten Filipino indigenous peoples"

BAGUIO CITY, Philippines - At least a hundred indigenous women and men in their traditional attire braved the monsoon rains here as they marched down Session Road to mark World Indigenous Peoples Day and to call attention to life-threatening issues affecting Filipino IPs.

(Dumlao, 2016)

The data shows that IPs-related issues seem to be recurring throughout the five years. For instance, a similar incident took place in 2012 under the headline "Aquino urged to stop killings of mining foes" (Inquirer. Net, August 1, 2012) and "B'laan tribe laments 'massacre' of leader's family" (Rappler, October 18, 2012). Although extract (7) and the two other headlines just cited did not exemplify the action theme, they all narrated the unfortunate situation of the indigenous group who stood up in defense of their ancestral land against the mining operation.

(7) "Protesters from Mindanao storm mining company in Makati"

MANILA, Philippines-About 50 environmental advocates from Mindanao stormed the headquarters of a mining company... to protest the alleged killings and displacement of indigenous peoples in their communities.

(Hegina, 2014)

In an interview with the spokesperson of an NGO based in Palawan, she confirmed that IPs' displacement is one of the pressing issues brought along by mining operations. She emphasized that said issue should be addressed by the authorities and should not simply be ignored.

The highlights of 2017 were the release of the mining audit's result in February, and the rejection of Gina Lopez as DENR Secretary. The news article with the headline in (8) talked about the clashing views from people from different walks of life, as may be seen in the second sentence of the said article shown in (9).

(8) "CA verdict on Gina draws mixed reactions"

(9) Malacañang and the Department of Finance said that they respect the decision of the CA, while Sen. Joseph Victor "JV" Ejercito, environmental groups and church leaders slammed the verdict.

(Kabiling et al., 2017) 
Although it is presupposed by the Constitution that government's mandate supersedes all other possible conflicting interests such as pure economic gains to the detriment of the natural resources and the ecosystem of the country, striking a balance between development and preservation of natural resources is far from easy. It sits between the fences of the government and the mining industry, both in the opposite poles that any movement or action will affect each other's end.

\section{ON ACTOR THEME}

The two news articles below highlight the social actors involved. Extract (10) foregrounds the individualized social actors, the anti-mining advocates, who praise the policy, while extract (11) focuses on the Congress, a collectivized group, who takes on the call of the President during his 2012 SONA, to pass a legislation similar or supporting E.O. 79.

(10) "Anti mining advocates cheer Aquino policy, but..."

Ardent antimining advocate Gina Lopez cheered President Benigno Aquino for making a stand to protect the environment.... [Emphasis Added]

(Anda, 2012)

(11) "Congress studies mining revenue bill: Measure important but difficult to pass without Palace certification - SB"

MANILA, Philippines - House Speaker Feliciano Belmonte Jr. yesterday said that a bill rationalizing the revenue sharing between the state and mining companies.... [Emphasis Added]

(Valencia, 2012)

The collectivized social actors who received the spotlight from the media are presented in Table 2. Collectivization occurs when discourse participants are being referred to as a group acting as a unified entity (e.g., the committee, the industry) (van Leeuwen, 2008).

TABLE 2. The top-20 List of Social Actors realized through Collectivization $(\mathrm{N}=517)$

\begin{tabular}{|c|c|c|c|c|c|c|c|}
\hline \multirow[t]{2}{*}{ Social Actors } & \multicolumn{7}{|l|}{ Year } \\
\hline & 2012 & 2013 & 2014 & 2015 & 2016 & 2017 & Total \\
\hline the government & 25 & 7 & 3 & 4 & 18 & 15 & 72 \\
\hline the company & 9 & 13 & 9 & 9 & 24 & 5 & 69 \\
\hline the DENR & 3 & - & - & 3 & 23 & 21 & 50 \\
\hline Philex & 7 & 11 & 1 & - & 5 & 11 & 35 \\
\hline the Philippines & 5 & 7 & 11 & 1 & 9 & 1 & 34 \\
\hline the country & 3 & 2 & 5 & - & 9 & 5 & 24 \\
\hline the community & 1 & 1 & 3 & - & 9 & 9 & 23 \\
\hline mining firms & - & - & - & 1 & 3 & 17 & 21 \\
\hline the group & 4 & 1 & - & 3 & 3 & 10 & 21 \\
\hline the MGB & 5 & 1 & 6 & 6 & 1 & 2 & 21 \\
\hline SMI & 7 & 2 & 8 & 2 & - & - & 19 \\
\hline mining companies & 3 & - & - & 1 & 5 & 8 & 17 \\
\hline the COMP & 4 & - & 1 & - & 6 & 6 & 17 \\
\hline
\end{tabular}




\begin{tabular}{|c|c|c|c|c|c|c|c|}
\hline the industry & 4 & 1 & 1 & - & 5 & 6 & 17 \\
\hline the mining industry & 4 & - & - & - & 5 & 7 & 16 \\
\hline COMP & 2 & - & 1 & - & 5 & 5 & 13 \\
\hline $\begin{array}{l}\text { the Department of Environment and } \\
\text { Natural Resources (DENR) }\end{array}$ & 4 & 1 & 4 & - & 3 & 1 & 13 \\
\hline the MICC & 3 & - & 2 & - & - & 8 & 13 \\
\hline the companies & 1 & 1 & - & - & 6 & 3 & 11 \\
\hline $\begin{array}{l}\text { the Mines and Seosciences } \\
\text { the Bureau (MGB) }\end{array}$ & 1 & 1 & 2 & 3 & 2 & 2 & 11 \\
\hline Total & 95 & 49 & 57 & 33 & 141 & 142 & 517 \\
\hline
\end{tabular}

*Note. Zeroes were represented by dashes.

Table 2 displays that the government, the company, the DENR, Philex, and the Philippines gained the highest aggregated frequencies in the five-year period. Of those in the list, the government garnered the highest frequency which signifies its critical role played in the mining issues. Section 2, Article XII of the 1987 Constitution explicitly states its full control in the "exploration, development, and utilization of mineral resources" (p. 1) justifying its constant manifestation in the data throughout the period. Its highest frequency was recorded in 2012 which was triggered by the issuance of the mining policy.

The higher frequencies of the government in 2016 and 2017 are reflective of the political landscape of the country such as the installation of the Duterte Administration on June 30, 2016, the appointment of the staunch anti-mining advocate Gina Lopez as DENR secretary, among other moves initiated by the government. For example, the DENR secretary's launching of an audit on all mining operations resulted in suspension and closure of almost two-thirds of the mining firms in the country that resulted in various social issues (e.g., unemployment) and political conflicts.

The company, a referent of various mining firms, gained the second highest frequency in the data. Among the mining firms, Philex was most represented in the news as suggested by its frequency in Table 2. Apparently, its recurrence in the data was motivated by a disaster that it caused on August 01, 2012, discharging some 20.7 million tons of its accumulated tailings to the Balog and Agno Rivers in Benguet.

Table 2 further shows that the four dominant groups in the data include: the government (DENR, MGB, MICC); the mining sector (e.g., Philex, COMP, SMI); the group representing various NGOs; and 'the community' in which the Philippines and the country could also be subsumed. The combined frequencies of the entities under each group revealed the government and the mining sector are more widely represented than the NGOs and other groups. This finding is not surprising because these two dominant groups are at the heart of the mining sector, who also weld the discourses in the industry. However, the seemingly underrepresentation of green/civic groups in the data echoes Deacon et al. (2015) and Haikola and Anshelm's (2016) observation of the subtle downplaying of the affected mining communities by the media.

The 20-most-occurring individualized social actors are presented in Table 3. 
TABLE 3. Top-20 List of individualized Social Actors ( $\mathrm{N}=496)$

\begin{tabular}{|c|c|c|c|c|c|c|c|}
\hline \multirow{2}{*}{ Formalization } & \multicolumn{7}{|l|}{ Year } \\
\hline & 2012 & 2013 & 2014 & 2015 & 2016 & 2017 & Total \\
\hline Lopez & 2 & - & - & - & 51 & 135 & 188 \\
\hline Duterte & - & - & - & - & 13 & 45 & 58 \\
\hline Cimatu & - & - & - & - & - & 33 & 33 \\
\hline Habitan & - & 22 & - & 4 & - & - & 25 \\
\hline Dominguez & - & - & - & - & - & 23 & 23 \\
\hline Jasareno & 11 & - & 3 & - & 9 & - & 23 \\
\hline Recidoro & - & - & - & - & 8 & 14 & 22 \\
\hline Siman & - & 15 & - & - & - & - & 15 \\
\hline Ricafort & - & 13 & - & - & - & - & 13 \\
\hline Belmonte & 12 & - & - & - & - & - & 12 \\
\hline Villar & - & - & - & - & 11 & - & 11 \\
\hline Pangilinan & 5 & 2 & - & - & 3 & - & 10 \\
\hline Bravo & - & - & - & - & 6 & 3 & 9 \\
\hline Salazar & - & - & 8 & - & - & - & 8 \\
\hline Legarda & 7 & - & - & - & - & - & 7 \\
\hline Abella & - & - & - & - & - & 7 & 7 \\
\hline de Jesus & - & 1 & - & - & - & 6 & 7 \\
\hline Umali & 4 & 3 & - & - & - & - & 7 \\
\hline Binay & - & - & 1 & 7 & - & - & 7 \\
\hline Tolentino & - & - & - & - & - & 6 & 6 \\
\hline Total & 44 & 56 & 12 & 11 & 109 & 303 & 496 \\
\hline
\end{tabular}

Of the 20 names in the list, 14 belong to government officials occupying the key positions in the country (e.g., president, vice-president, senator, governor, DENR secretaries and directors, and presidential spokesperson) four (4) belong to the "elites" in the mining sector: Recidero, COMP vice-president for legal and policy matters; Ricafort, Philex resident manager and vice-president for operations; Bravo, President of Ferronickel Holdings, Inc.; and Pangilinan, Chairman Philex Mining Corp.; and two (2), "big time" pocket miners Habitan and Siman, who became notorious because of their alleged involvement in illegal business dealings and both ended up in 'controversial' deaths.

Table 3 signifies that the more prominent the social actors are, the more they are given space in the news reports. A contradiction may, however, be observed as the surname of former President Aquino gained an unexpected low frequency, appearing only five (5) times in the data despite his 'controversial' mining policy and considering his term of office covers most of the period (2012-2015) specified in this study. His successor, Duterte, ranked second in the list in a matter of less than two year's media coverage. 
Undeniably, the frequencies of the social actors in Table 3 explains the socio-political circumstances of the country during the given period. The relatively high figures in 2012 and 2013 could be linked to President Aquino's issuance of E.O. 79 in the middle of 2012; hence, its effects were felt in the subsequent year. Frequencies in 2014 and 2015 were the lowest, involving a very few social actors: Jasareno, MGB Director, Salazar, Zamboanga City Mayor, Binay in 2014; and only Habitan and Binay recurred in 2015. The peak of mining issues was in 2016 and 2017 as may be seen by the highest frequencies recorded in these years as well as the various social actors involved. As have been discussed, the mining industry was struck by the Duterte administration's anti-mining drive as dubbed by the President Duterte himself as the "sunset industry."

The absence of "ordinary" persons' surnames in the top-20 list indicates that they are not given primacy by the media the way prominent actors did. This kind of discursive construction implies a play of power. Please note that prominent individuals were represented 827 times in the data using nomination strategies, referring to actors by their unique identity (e.g., first and/or surname with/without honorifics) (van Leeuwen, 2008). On the other hand, "ordinary" citizens were discursively constructed in the data only 129 times through categorization strategies - referring to actors using identities they share with others or of what they do (van Leeuwen, 2008) such as workers, protesters, victims. They were only nominalized whenever they were involved in unfortunate events (e.g. mine accidents, crimes). This seemingly preferring the "elite" members of the community resonates the elite theory's assumption that "the values and preferences of the general public are less influential... than those of... elites" (Dye 2001; Dye \& Zeigler 2003 in Kraft \& Furlong, 2007, p. 65). That is, the tendency of the media to celebrate the ideas or discourse positions of the 'expert' members because of the notion that words are not powerful by themselves but are made so by powerful individuals who created them (Reisigl \& Wodak, 2009).

\section{ON PHENOMENA THEME}

Table 4 summarizes the subcategories of the phenomena theme as reflected in the five-year news reportage of online newspapers.

TABLE 4. Distribution of news themes under Phenomena category from 2012 to 2017

\begin{tabular}{llllll}
\hline Year & Phenomena & & & \\
\cline { 2 - 5 } & Economic & Environmental & Social & Political & 11 \\
\hline 2012 & 3 & 3 & 2 & 3 & 9 \\
2013 & 5 & 1 & 2 & 1 & 13 \\
2014 & 6 & 2 & 4 & 1 & 13 \\
2015 & 6 & 2 & 3 & 2 & 19 \\
2016 & 14 & 1 & 3 & 3 & 12 \\
2017 & 4 & 3 & 2 & 12 & 77 \\
\hline
\end{tabular}

Table 4 reveals a stark contradiction between the economic (40 or 51.95\%) and environmental phenomena ( 9 or $11.25 \%$ ) categories in terms of frequency. The economic theme soared in 2016 which probably triggered the suspension and closure of the majority of the mining firms in the country. This initiative of the DENR is believed to have disrupted the 
global market chain in terms of supply and prices of metals. The most prevalent theme was the displacement of mine workers and its projected effects to the quality of life of their families as well as other social services provided by the government (e.g. infrastructure projects derived from the mining sector's taxes), as can be seen in the extract below.

(12) "Mass starvation feared after closure of mines in Surigao del Sur"

CANTILAN, Surigao del Sur - Over 7,000 people who depend on mines for their living will starve in this town even before Environment Secretary Gina Lopez can put in place an ecotourism program to provide them with alternative livelihoods, officials warned on Saturday.

(Panganiban, 2017)

The news article in (12) highlights the economic impact of the mining suspensions in the country. The quantification of the social actors, "over 7,000 people" is an intensification strategy and a pressuring tactic that could reverse the perspective of the authorities involved and could influence the opinion of the public about the issue.

The tendency of the media to frame mining issues from economic perspective rather than from the environmental aspect of mining issues as may be seen in the following extracts. This finding somehow agrees with Castrechini et al.'s (2014) conclusion that media representations of environmental issues shifted from being associated with nature to urban environment and development.

(13) "Semirara, 1st-half net falls by $20.6 \% "$

Semirara Mining Corp., the country's biggest coal producer, posted a 20.6- percent drop in income to P3.63 billion in the first half of 2012 from P4.58 billion a year ago.

(Remo, 2012)

Extract (13) revolves around the company's loss. The lead even details the exact deficit incurred by the company. This manner of representing the economic phenomena is consistent with those found in other years such as in the headlines below.

$$
\text { "Metal output rises to P23.7B in Q1" }
$$

(Valencia, 2015)

$$
\text { "Nickel ore shipments from PH seen cut 30\%" }
$$

(Bloomberg, 2016)

Moreover, the somewhat downplaying of the media on the environmental impact of mining operations may be seen below.

(16) "Philex goldmine suspended over spill"

The government has indefinitely suspended the operations of the country's largest gold mine after a waste spillage near a major river, officials said on Monday.

(Inquirer.Net, August 06, 2012)

It was noticed that the extent of spillage was not highlighted in the news report despite the possibility that the toxic substances from the tailing pond have reached the major waterways in the province. There was no mention of the amount of toxic that escaped from the leaked pond or details about the possible damage to the environment or livelihood of the nearby communities. The lamest excuse for the seemingly downplaying of the issue perhaps is to avoid causing panic from the public or to omit some facts that needed further verification, or to protect some ends (Fairclough, 1989). Wodak and Meyer $(2001,2009)$ observe that media institutions often describe themselves to be neutral but Fairclough (1989) proves it otherwise by showing how the media framed societal events to favor certain perspectives. 
Table 4 further shows that although the social phenomena (17 or $21.25 \%$ ) comes second in the list, a huge disparity in terms of frequencies between the economic theme and this category is noticeable. Issues dealing with the plight of indigenous peoples (IPs) are subsumed under this category. This finding implies that concerns over marginalized groups (e.g., IP communities) do not receive significant attention from the media. This means that the media failed to capture Schipper's (2010 as cited in Conde, 2017) observation that indigenous rights in the Philippine were employed as a strategy to stop a project or to obtain from the company or the State.

\section{LOCAL NEWS REPORTS}

Table 5 presents the distribution of themes evinced in the local news reports published by The Palawan Times (TPT) for the 2015- 2017 period.

TABLE 5. Distribution of themes in the local news reports from 2015 to 2017

\begin{tabular}{|c|c|c|c|c|c|c|c|}
\hline \multirow[t]{2}{*}{ Year } & \multicolumn{2}{|c|}{ Actors } & \multicolumn{3}{|c|}{ Actions } & \multicolumn{2}{|c|}{ Phenomena } \\
\hline & $* \mathrm{PA}$ & $\mathrm{OC}$ & GOV & $\mathrm{NGO}$ & $\mathrm{MC}$ & EN & Total \\
\hline 2015 & 1 & $-* *$ & 2 & - & 3 & - & 6 \\
\hline 2016 & 1 & 1 & 4 & 4 & 5 & 2 & 17 \\
\hline 2017 & 1 & 1 & 4 & 1 & - & - & 7 \\
\hline Total & 3 & 2 & 10 & 5 & 8 & 2 & 30 \\
\hline
\end{tabular}

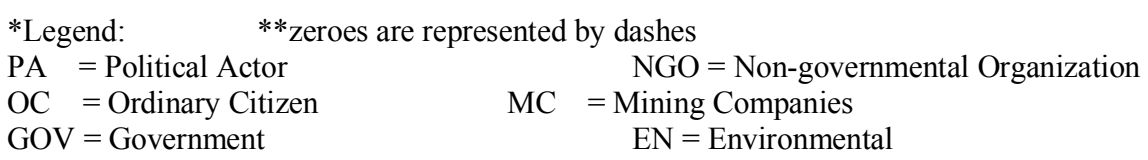

Table 5 shows that the action theme dominated the data. Among the four sub-themes identified in the national news, only individual action theme is nonexistent in the local media. Among the remaining three sub-themes, the government gained the highest frequency (10 or $33.33 \%$ ), followed by mining companies ( 8 or $26.66 \%$ ) and NGOs (5 or $16.66 \%$ ). The aggregated frequencies of the collectivized social actors comprised more than three quarters $(76.66 \%)$ of the entire data. This finding signifies the leaning of local media to report collective than individualized actions particularly those of the prominent environmental groups in the province (e.g., Environmental Legal Assistance Center, Palawan NGO Network, Inc.).

\section{NATIONAL VERSUS LOCAL MEDIA REPRESENTATION}

The province of Palawan receives special attention from the national government when it comes to safeguarding its environment and natural resources. For instance, as early as 1992 the Philippine Congress already enacted Republic Act 7611, the Strategic Environmental Plan for the province which subsequently created the Palawan Council for Sustainable Development to ensure proper management, preservation, and conservation of its natural wealth. Likewise, the national media tends to report environmental issues of the province more often than other provinces as shown in its frequency in the data. The news report under the headline "Aquino memo to DENR: No new mining permits in Palawan" published by Inquirer.Net on July 11, 2012 showed that the President was specifically directing the DENR Secretary, Ramon Paje, to "desist from processing mining applications" in the province. This is one of the specific 
instructions of Malacañang stipulated in a memorandum for DENR to ensure compliance with the provisions of E.O.79. It was even viewed as a "surprise that Malacañang came up with a specific action for Palawan only, which was among the 78 tourism sites declared by EO 79 as 'no-go' zones" (Inquirer.Net, July 11, 2012, para. 4). The article further describes mining as "....a touchy issue in Palawan" (para. 8).

To compare the national and local media's representation of mining issues, a particular event which they both reported, was chosen and discussed. One of the controversial mining issues that caught the attention of the local and national media was the clearing of about 20 hectares of forest in a town by a mining company for its operation. The said event made it to the front page and news pages of national newspapers with the headlines "Where have all trees gone: Lopez accuses mining firm of 'massacre' in Palawan" (Tempo, May 19, 2017), "Palawan town to sue miner for clearing forest", "Chainsaw massacre of Palawan forest probed", and "Nickel firm insist tree cutting in mining site legal, covered by permit" (Inquirer.Net, May 19, 21, 24, 2017).

The national and the local media presentation of the issue shows some slight differences. In terms of angle, the national media focuses on the "what" or the action and the extent of such actions as implied by the headlines "Where have all trees gone..." and "Chainsaw massacre of Palawan forest...". In terms of social actors' representation, five out of six nominalized social actors are the key DENR national officials, the lone local social actor that specifically named in the report was the municipal mayor of the town where the said treecutting issue happened. The rest of the discourse participants were categorized such as: company workers, mining officials, reporters, staff among others functional labels, or collectivized highlighting the concerned mining company, the local government unit, DENR party among others. While Inquirer.Net published three news reports on the said event dated May 18, 19, and 21, 2017, the two other national print media, Manila Bulletin and The Philippine Star made no publication on the said event.

The local media's representation of the event seems to foreground the action of the prominent social actor, the DENR Secretary, and not the action committed by the company as cued by the headline "Cimatu orders halt to Ipilan Nickel Mining Corp. tree cutting" published by The Palawan Times on its May 14-20, 2017 weekly issue. Also found in the said issue is a separate article with the headline "PLETF, PNNI confiscate chainsaws in separate operations", reporting the clearing and cutting operation of the mining company in question. There were no other follow-up reports published after this weekly issue.

What is interesting in these representations is a lot of personalization. The news reports' leaning on the value of reference to elite persons lead to news frames that downplay issues in terms of "individual faults, mistakes, gains, losses" (Mayr, 2008, p.76.) We learn that Cimatu orders to halt the mining or PNNI confiscate chainsaws, but these have simply personalized an action, and we learn little of its impact on the larger environmental national policies. Hence personalization also leads to fragmentation, because it does not lead us to learn more about the environmental policies that prompted it in the first place. What we see is its reduction to acts and what is newsworthy about it is the fact that Palawan becomes an elite place for mining and the involvement of high-ranking officials in activities related to it. In general, the discourses of more "influential" groups, those of the government and the mining "elites" were given voices over the "experiencers of the events" (p.81) such as the residents affected or the crime offenders. 


\section{CONCLUSION}

Drawing on CDA, this study attempted to describe mining discourse based on the media's representation of mining issues in the Philippines. The mainstream discourses reflected in the national news reports were supplemented by peripheral discourses obtained from the local media and significant personalities following a top-down model of analysis. Results show that the national media focused on government actions, economic phenomena and political actors while the local news centered on the actions of civic groups and private sectors. Moreover, national media's tendency to extensively report issues concerning 'dominant groups' (e.g., economic, political) and the local media's leaning on 'particularistic' issues relating to 'marginalized' groups such as children with physical conditions and less privileged communities suggests the prioritization or thematization schemes observed by the text producers when construing social realities.

In this case, the media plays a role vital in the construal of mining discourse in the country. Its formidable power lies on its sole producing rights in determining what/who can be included and excluded in the text, how events are being represented, and how the readers are being positioned in the texts (Fairclough, 1989). This notion seems to explain the manifestation and non-manifestation of some themes in the data, an indication that indeed the media's recontextualization of events serves some ends. For example, the foregrounding of economic issues related to the proposed banning of mining operations in the country and the seemingly downplaying of its impact to the environment and livelihood of the people in the community may reveal the text producers' discourse positioning and leaning. Thus, the media's (re)presentation and (re)contextualization of reality can change the public's belief and can move them into action towards a direction implicitly or explicitly construed in the discourse.

Because of the media's tendency to appropriate more space for the discourse position of prominent personalities, the "powerful" social actors, in this context, are the prominent personalities from different sectors who can influence the production and circulation of discourses. This exercise of shaping or re-shaping the discourses of the "dominated" ones is not at all impossible because language use or discourse has constitutive relationship with its specific context and social structure (Encinas-Franco, 2013; Fairclough, 1989). That is, discourse is socially constituted and at the same time socially constitutive.

Finally, the perception that mining discourse anchors heavily on the grounds of environmental protection and other similar concerns was not concretized in the data. What appeared to be the distinct characteristic of the country's mining discourse is the prominence of economic discourses. As discussed, there was a seemingly downplaying of the environmental issues while foregrounding the economic benefits of the mineral industry. Moreover, mining discourse seems to be associated with political discourse. This observation coincides with Castrechini et al's (2014) conclusion that environmental discourse shifts from "scientific discourse to political discourse" (p.219) as it is no longer exclusive for ecologists and green groups but is already assumed by celebrities and public personalities. Thus, 'understanding' of mining issues and their associated environmental issues is a pressing problem that needs to explore new ways forward, to facilitate worthwhile discussion among the concerned parties such as government agencies, civic groups, environmental advocates, and the mining communities. A thorough understanding of mining issues especially by those who are directly affected by the extractive industry's operations such as the 'grassroots' or ordinary members of the community as well as the indigenous peoples should become the motivation of those in 'power'. Moreover, the value of protecting the environment should not be abandoned by 'powerful' social actors and should be collectively advocated by everyone in the country for sustainable development not only of Philippine society but of humanity in general. 


\section{REFERENCES}

Abanes, M. S. (2005). People's Organizations (POs), Non-Government Organizations (NGOs), and the Catholic Church vs. The State and a Transnational Corporation (TNC): A Critical Discourse Analysis of Mining Issues in Rapu-Rapu Island, Albay. Ateneo de Naga University Journal, 1-27.

ALDAW, \& CBCD. (2010). “The Bulanjao 2010 Geo-Tagged Report” Mining Aggression In Core Zones And Ecologically Fragile Areas On Palawan Island (The Philippines. Centre for Biocultural Diversity (CBCD) of the University of Kent (UK).

ALDAW, \& CBCD. (2010). “The Bulanjao 2010 Geo-Tagged Report” Mining Aggression In Core Zones And Ecologically Fragile Areas On Palawan Island (The Philippines. Centre for Biocultural Diversity (CBCD) of the University of Kent (UK). http://www.iapad.org/wp-content/uploads/2015/07/aldaw bulanjao_2010_report.pdf

Anda, et. al. (2012, July 10). Anti-mining advocates cheer Aquino Policy but... Inquirer.Net. https://newsinfo.inquirer.net/226242/antimining-advocates-cheer-new-aquino-policybut

Benagen, M. (1998). Estimation of Environmental Damages from Mining Pollution: The Marinduque Island Mining Accident. Singapore: The Economy and Environment Program for South East-Asia (EEPSEA).

Carvalho, A. (2005). Representing the politics of the greenhouse effect: Discursive strategies in British media. Critical Discourse Studies, 2, 1-29.

Castrechini, A., Pol, E., \& Guàrdia-Olmos, J. (2014). Media representations of environmental issues: From scientific to political discourse. Elsevier Masson SAS, 2013-220.

Chaloping-March, M. (2011). The trail of a mining law: 'Resource nationalism' in the Philippines. Mining and Mining Policy in the Pacific: History, Challenges, and Perspectives. Noumea, New Caledonia.: Philippines-Australia Studies Centre, Institute for Human Security.

Clemente, E. D. (2019). Challenges in the Philippine mining industry. Philippine Institute for Development Studies' Policy Notes. https://pidswebs.pids.gov.ph/CDN/PUBLICATIONS/pidspn1904.pdf

Cordero, T. (2017, February 03). PHL mining group says mine closures, suspension to affect 1.2 million people. (2017, February 3). GMA Online. http:// www.gmanetwork.com/news/story/598171/money/companies/phl-mining-group-saysmine-closures-suspension-to-affect-1-2-million-people

Dangcalan, D. (2012, July 15). Honasan seeks discussion on new mining EO's restrictions on LGUs. The Philippine Star. http://www.philstar.com/headlines/2012/07/15/827966/honasan-seeks-discussionnew-mining-eos-restrictions-lgus

Deacon, L., Baxter, J., \& Buzzelli, M. (2015). Environmental justice: An exploratory snapshot through the lens of Canada's mainstream news media. The Canadian Geographer / Le Geographe canadiene, 59(4), 419-443.

Delina, L. L. (2020). Topographies of coal mining dissent: Power, politics, and prospects in $\begin{array}{llll}\text { southern } \quad \text { Philippines. } & \text { Word }\end{array}$ https://doi.org/10.1016/j.worlddev.2020.105194

Domingo, R. (2014, March 8). PH has 3rd worst mining policy regime. Inquirer.Net. http://business.inquirer.net/165657/ph-has-3rd-worst-mining-policy-regime

Domingo, R. (2016, June 7). Big miners back Duterte. Inquirer.Net. http://newsinfo.inquirer.net/789404/big-miners-back-duterte 
Domingo, R. (2016, September 1). PH mining stance to disrupt the global nickel market. Inquirer.Net. http://business.inquirer.net/214319/ph-mining-stance-to-disrupt-globalnickel-market

Domingo, R. (2016, September 17). Mining giants prepare for the release of the DENR audit. Inquirer.Net. http://business.inquirer.net/215027/mining-giants-prepare-for-release-ofdenr-audit

Dumlao - Abadilla D., Nawal, A. (2017, February 28). DENR shuts down 23 mining firms. Inquirer.Net https://newsinfo.inquirer.net/867793/denr-shuts-down-23-miningareas

Duterte, R. (2016, July 25). The 2016 State of the Nation Address. Official Gazette of the Republic of the Philippines. http://www.gov.ph/2016/07/26/the-2016-state-of-thenation-address/

Encinas-Franco, J. (2013). The language of labor export in political discourse: Modern-day heroism and constructions of overseas Filipino workers (OFWs). Philippine Political Science Journal, 34(1), 97-112.

Fairclough, N. (1989). Language and Power. Longman.

Fairclough, N. (2001). Critical discourse analysis as a method in social scientific research. In R. Wodak, \& M. Meyer, Methods of critical discourse analysis (pp. 121-138). SAGE Publishing.

Fairclough, N. (2009). Critical discourse analysis as a method in social research. In R. Wodak, $\&$ M. Meyer, Methods for critical discourse analysis (pp. 162-187). SAGE Publishing.

FESS. (2007). A Double-Edged Sword? Implications of Mining for Environmental Security in the Philippines. Sustainability, Foundation for Environmental Security and Sustainability. Washington: $\quad$ FESS. https://www.fessglobal.org/Publications/Other/philippines_esaf_report.pdf

Gamil, J.T. (2016, August 29). Gina defends DENR exec; 'not happy' with another. Inquirer. Net. https://newsinfo.inquirer.net/700153/gina-defends-denr-exec

Garlitos, P. A. L. (2020). Shades of green reporting: A critical discourse analysis of eco-news reports in the Philippines. Journal of Language and Literature, 20(1), 25-39. https://ejournal.usd.ac.id/index.php/JOLL/article/view/2381/1790

Gascon, M. (2015, June 23). Black sand mining in Cagayan goes off shore. Inquirer. Net. https://newsinfo.inquirer.net/700153/black-sand-mining-in-cagayan-goes-offshore

Gigantone, C. B., Sobremisana, M. J., Trinidad, L. C., \& Migo, V. (2020). Impact of abandoned mining facility wastes on the aquatic ecosystem of the Mogpog River, Marinduque, Philippines. Journal of Health \& Pollution, 10(26), 1-12. https://doi.org/10.5696/21569614-10.26.200611

Haikola, S., \& Anshelm, J. (2016). Mineral policy at a crossroads? Critical reflections on the challenges of expanding Sweden's mining sector. The Extractive Industries and Society, $3,508-516$.

Hakam, J. (2009). The 'cartoon controversy': A critical discourse analysis of English-language Arab newspaper discourse. Discourse \& Society, 33-57.

Halliday, M., \& Mattheissen, C. (2004). An Introduction to Functional Grammar (3rd Edition ed.). Hodder Arnold.

Halliday, M., \& Mattheissen, C. (2004). An Introduction to Functional Grammar (3rd Edition ed.). Hodder Arnold.

Hegina, A. J. (2014, November 25). Protesters from Mindanao storm mining company in Makati. Inquirer Net. https://newsinfo.inquirer.net/652741/protesters-from-mindanaostorm-mining-company-in-makati 
Ingelson, A., Holden, W., \& Bravante, M. (2009). Philippine Environmental Impact Assessment, Mining, and Genuine Development. Law, Environment and Development Journal, 5(1), 1-17.

Kabiling, G. (2017, February 2). Duterte gives full support to DENR chief's pro-people, propoor policy. Manila Bulletin Online. https://news.mb.com.ph/2017/02/02/dutertegives-full-support-to-denr-chiefs-pro-people-pro-poor-policy/

Kabiling, G., Leyco, S. Casayuran, M., De Vera Ruiz, E., Aquino, L. (2017, May 4). CA verdict on Gina draws mixed reactions. Manila Bulletin Online. https://news.mb.com.ph/2017/05/04/ca-verdict-on-gina-draws-mixed-reactions/

Kraft, M. E., \& Furlong, S. R. (2007). Public Policy: Politics, Analysis, and Alternatives (2nd ed.). CQ Press.

Leipold, S., Feindt, P. H., Winkel, G., \& Keller, R. (2019). Discourse analysis of environmental policy revisited: traditions, trends, perspectives. Journal of Environmental Policy \& Planning, 21(5), 445-463. https://doi.org/10.1080/1523908X.2019.1660462

Lucas, D. (2014, October 13). Mining hobbled by gov't 'fixation' on taxes Inquirer.Net. http://newsinfo.inquirer.net/226860/mining-hobbled-fixation-taxes

Machin, D. (2008) New discourse 1: Understanding the social goings-on behind news texts. In Mayr, A. (Ed) Language and Power: An Introduction to Institutional Discourse. Continuum.

Mayr, A. (2008). Language and Power: An Introduction to Institutional Discourse. Continuum.

Meyer, C. (2009). Introducing English Linguistics. Cambridge University Press.

Mohd Nor, N. F., Jeffree, N. B., \& Mohd Nor, H. A. (2021). Health is wealth: A corpus-driven analysis of the portrayal of mental health in Malaysian English online newspapers. GEMA Online Journal of Language Studies, 21(2), 46-71. http://doi.org/10.17576/gema-2021-2102-03

Nawal, A., \& Zonio, A. (2012, October 21). Tribal war feared over killings of Blaan members. Inquirer.Net. http://newsinfo.inquirer.net/293184/tribal-war-feared-over-killings-ofblaan-members

Özen, H., \& Özen, S. (2016). What makes locals protesters? A discursive analysis of two cases in the gold-mining industry in Turkey. World Development, 20, 1-12.

Panganiban, C. (2017, February 19). Mass starvation feared after the closure of mines in Surigao del Sur. Inquirer.Net. http://newsinfo.inquirer.net/872919/mass-starvationfeared-after-closure-of-mines-in-surigao-del-sur

Pennycook, A. (2010). Language as a Local Practice. Routledge.

PH-EITI. (2015). Elevating Transparency: The 2nd PH-EITI Report (FY 2013). Extractive Industries Transparency Initiative. https://www.pwc.com/ph/en/industries/industrypublications/industry-pwc-2nd-ph-eiti-report-fy2013.html

Plumlee, G. S., Morton, R. A., Boyle, T. P., Medlin, J. H., \& Centeno, J. A. (2000). An Overview of Mining-Related Environmental and Human Health Issues, Marinduque Island, Philippines: Observations from a Joint U.S. Geological Survey - Armed Forces Institute of Pathology Reconnaissance Field Evaluation, Denver: U. S. Geological Survey. https://doi.org/10.3133/ofr2000397

Reisigl, M., \& Wodak, R. (2009). The Discourse Historical Approach. In R. Wodak, \& M. Meyer, Methods of Critical Discourse Analysis (2nd ed., pp. 87-121). SAGE Publishing.

Reuters. (2016, September 20). Manila Bulletin Online. Philippines finds Semirara Mining's coal project 'technically sound. https://2016.mb.com.ph/2016/09/20/philippinesfindssemiraraminingscoalprojecttechni callysound/ 
Reuters. (2016, September 27). Philippines to suspend 20 more mines, boosting nickel price. https://www.reuters.com/article/us-philippines-mining-idUSKCN11X0DP

Sikka, T. (2012). A critical discourse analysis of geoengineering advocacy. Critical Discourse Studies, 163-175.

van Dijk, T. (2009). Critical discourse studies: A sociocognitive approach. In R. Wodak, \& M. Meyer, Methods of Critical Discourse Analysis (2nd ed., pp. 62-86). SAGE Publishing. van Dijk, T. A. (1988). News as Discourse. Lawrence Erlbaum Associates.

van Leeuwen, T. (2008). Discourse and Practice New Tools for Critical Discourse Analysis. Oxford University Press.

Wodak, R. (2001). The discourse historical approach. In R. Wodak, \& M. Meyer, Methods of Critical Discourse Analysis (pp. 63-93). SAGE Publishing.

Wodak, R. (2011). The discourse of politics in action: Politics as usual. Palgrave.

Wodak, R., \& Meyer, M. (2009). Methods of critical discourse analysis (2nd ed.). SAGE Publishing.

\section{ABOUT THE AUTHORS}

Jennifier T. Diamante holds the degree PhD in Applied Linguistics from De la Salle UniversityManila. She is currently an Assistant Professor at the College of Arts and Sciences of Western Philippines University. Her research interests focus on language teaching and critical discourse analysis.diamantejennifier12@gmail.com

Glenda Doroja-Cadiente received her PhD in Applied Linguistics in 2019 at De La Salle University-Manila. Her interests are Critical Sociolinguistics, Critical Discourse Analysis, and Language Education. Her dissertation centered on institutional discourse, analyzing doctorinformant talk in the context of a decentralized health system in the Philippines. gdoroja25@gmail.com

Romualdo Mabuan is Professorial Lecturer at the Institute of Education, Far Eastern University, Manila, Philippines. He received his $\mathrm{PhD}$ in Applied Linguistics (cand.) from De La Salle University-Manila. His research interests include discourse analysis, continuing professional development, $21^{\text {st }}$ century education, and TESOL. 